\title{
Why Teach Environmental Ethics? Because We Already Do
}

Raymond Benton Jr.

Loyola University Chicago, rbenton@luc.edu

Follow this and additional works at: https://ecommons.luc.edu/business_facpubs

Part of the Business Commons

\section{Recommended Citation}

Benton, Raymond, and Christine S. Benton. 2004. "Why Teach Environmental Ethics? Because We Already Do". World Views: Environment, Culture, Religion. 8 (2/3): 227-242. Available at http://dx.doi.org/10.1163/ 1568535042690790

This Article is brought to you for free and open access by the Faculty Publications and Other Works by Department at Loyola eCommons. It has been accepted for inclusion in School of Business: Faculty Publications and Other Works by an authorized administrator of Loyola eCommons. For more information, please contact ecommons@luc.edu.

\section{(c) $($ () $\ominus$}

This work is licensed under a Creative Commons Attribution-Noncommercial-No Derivative Works 3.0 License. (c) Brill, 2004. 


\title{
WHY TEACH ENVIRONMENTAL ETHICS? BECAUSE WE ALREADY DO
}

\author{
Raymond Benton, Jr. and \\ Christine S. Benton
}

\begin{abstract}
In this paper we argue for the importance of the formal teaching of environmental ethics. This is, we argue, both because environmental ethics is needed to respond to the environmental issues generated by the neoliberal movement in politics and economics, and because a form of environmental ethics is implicit, but unexamined, in that which is currently taught. We maintain that students need to become aware of the latent ethical dimension in what they are taught. To help them, we think that they need to understand how models and metaphors structure and impact their worldviews. We describe how a simple in-class exercise encourages students to experience the way metaphors organize feelings, courses of action, and cognitive understandings. This is then intellectualized by way of Clifford Geertz's concept of culture and his model for the analysis of sacred symbols. From there we present a brief interpretation of modern economics as the embodiment of the dominant modern ethos. This leads into a consideration of ecology as a science, and to the environmental ethic embodied in Aldo Leopold's "Land Ethic." We close with a personal experience that highlights how environmental teaching can make students aware of the presence of an implicit, but unexamined, environmental ethic.
\end{abstract}

Keywords: environmental ethics, environmental education, culture, neoliberal economics

\section{Introduction}

The question "why teach environmental ethics?" seems central to a collection of papers on the teaching of environmental ethics. We consider there to be two related reasons why environmental ethics should be taught. First, the last quarter century has witnessed the spread of neoliberal ideas and the concomitant increased reliance on market forces and the decreased reliance on non-market institutions, especially government. We suggest that Aldo Leopold, writing in the 1940s, well before environmental issues had entered the public consciousness, before the formation of the EPA, and before the passage of landmark environmental laws, foresaw the coming of this neoliberal turn. In his essay, "The Land Ethic," he wrote (1949: 213):

There is a clear tendency in American conservation to relegate to government all necessary jobs that private landowners fail to perform. 
Government ownership, operation, subsidy, or regulation is now widely prevalent in forestry, range management, soil and watershed management, park and wilderness conservation, fisheries management, and migratory bird management, with more to come. Most of this growth in governmental conservation is proper and logical, some of it is inevitable. That I imply no disapproval of it is implicitly in the fact that I have spent most of my life working for it. Nevertheless the question arises: what is the ultimate magnitude of the enterprise? Will the tax base carry its eventual ramifications? At what point will governmental conservation, like the mastodon, become handicapped by its own dimensions?

Leopold identified, in this passage, two issues that drive the neoliberal project - taxes and the ultimate size of government. He also gave voice to the neoliberal solution - increased reliance on the individual. "The answer," Leopold continued in the passage just quoted, "if there is any, seems to be in a land ethic, or some other force which assigns more obligation to the private landowner." According to this argument we should teach environmental ethics because it is likely to be the only answer to the environmental problems generated in the context of the neoliberal movement in politics and economics.

The other, related answer to the "Why" question is that we should teach environmental ethics because we already do. This will be explained in some detail as we explore an answer to a second question, "How should we teach environmental ethics?" In addressing this second question, we focus primarily on teaching environmental ethics to a particular kind of student: those taking an MBA. Teaching MBA students requires, we feel, a different approach than would be required if teaching, say, philosophy majors. MBA students expect to learn something one day and apply it the next. Most are not accustomed to ideological and intellectual introspection, and most do not see the point in it.

When we write about teaching environmental "ethics" to MBA students, we have in mind a broader, less precise meaning to the term than we suspect is most often conjured. As Des Jardins points out (2001: 17-18), the word ethics is derived from the Greek word ethos, meaning "custom." In this sense, he writes, "ethics refers to the general beliefs, attitudes, or standards that guide customary behavior." This is what we mean by ethics. Our meaning is more akin to what is meant by its use in the terms "the Puritan ethic" or "the work ethic." Our concern is not with explicating formal rules to be 
applied in decision-making contexts, but with explicating the beliefs, attitudes, values and standards that currently guide customary behavior. Our preferred term for what we are talking about is, in fact, ethos rather than ethics, and our jumping off point is not philosophy but anthropology, in particular the anthropology of Clifford Geertz. ${ }^{2}$

We do not view the teaching of ethics as an exercise in providing students with a new rulebook to follow. Instead, we view ethical responsibility as something that will come when students are given the critical thinking skills to self-reflect on their contemporary situation. Consequently, determining what or which environmental ethics should be taught falls outside the scope of this paper. Our main goal is to outline the initial steps that must be taken prior to tackling the "which environmental ethics" question. Suffice it to say, we would support an environmental ethics that respects different approaches to decision-making and different voices affected by those decisions. The environmental ethics that we would support would remain always contextually based, because to decide a course of action requires that the problem first be understood as situated and described as such.

Consequently, when we think about teaching environmental ethics we are thinking along the lines expressed, again, by Des Jardins who defined ethics as "a self-conscious stepping back from our lives to reflect on what we should do, how we should act, and what kind of people we should be" (2001: 6). To us this is what all education should be, and certainly should form the basis of a course in environmental ethics.

From our perspective, students need first to become aware of the latent ethical dimension in everything. But before that they need to understand how models and metaphors shape understanding, and then to become fully aware of which models and metaphors shape their own understanding. We begin with an in-class exercise that forces students to experience the way metaphors organize feelings, courses of action, and cognitive understanding. We then intellectualize this by way of Clifford Geertz's concept of culture and his model for the analysis of sacred symbols. We make reference to the dominant modern worldview before we briefly suggest an interpretation of modern economics as the embodiment of the dominant modern ethos. Then we venture into the realm of ecology as a science and take the road presented by Aldo Leopold's "The Land Ethic," tying it into the lineage of modern economics. 


\section{Thinking, Conceptualizing, and Analyzing}

Des Jardins writes: "a primary role of descriptive ethics is to make explicit the models and metaphors that shape our understanding of the world" (Des Jardins 2001: 157). But most students (and many professors) do not really grasp how models and metaphors shape their interpretations, understandings, feelings, and courses of action. Demonstrating this is the first step in our approach to teaching environmental ethics. The following is a brief in-class exercise that makes the point.

We ask students to imagine that they have been on a trip, during which they bought something. During their return travels home, they strike up a conversation with somebody. This conversation turns to that which they have bought and, eventually, to the price paid. Upon learning the price paid, the other person indicates that they got a steal, a bargain. At this point, we stop and ask the students to describe how they feel about what they have just been told. Then we ask them what they might do given the information that it was a bargain, a really cheap price for what they bought. Finally, we ask them what they know about the situation at hand (including the original purchasing situation).

To the "how do you feel" question, in varying forms most students respond that they would be happy, elated, or proud. Some respond that they would be suspicious of the person giving them this information - how would they know whether it was a good deal or not? Both responses, pride and suspicion, are recognizable responses to everybody in the class. In the scores of times that this exercise has been executed in class, only once did a student indicate they would feel guilty. As a response, it was not recognized as realistic by the rest of the class; they could not understand how anybody would feel guilty in such a situation.

To the "what would you do" question, a variety of similar responses are offered: some would tell others, either out of pride of their ability to shop or so the others can get the item as well; some might try to sell it and realize a profit; some indicate they would return and buy more; others say they will just feel good about it. All are recognizable responses in that they make sense to others in the class.

The question regarding "what they know" about the situation generally brings puzzlement. They often do not understand what is asked. If a response is given, it is often simply, "Just because." They 
develop the ability to understand the question, and how to respond to it, in the second part of this exercise.

In order to change the circumstances of the thought experiment, we stop at this point and suggest they transport themselves to another place or to another time. This "other place" is seriously religious and relies on an organic analogy to think about, conceptualize, and analyze social and economic relations. Without identifying sources, we read a few passages from historical sources so they can grasp for themselves how these other people "see the world." For example, we read a passage from Wycliff:

The Church is divided in these three parts, preachers, and defenders, and ... laborers. ... As she is our mother, so she is a body, and health of this body stands in this, that one part of her answers to another, after the same measure that Jesus Christ has ordained it.... Kindly man's hand helps his head, and his eye helps his foot, and his foot his body . . . and thus should it be in parts of the Church. ... as diverse parts of man served unkindly to man if one took the service of another and left his own proper work, so diverse parts of the Church have proper works to serve God; and if one part leaves his work that God has limited him and take work of another part, sinful wonder is in the Church.... Surely the Church shall never be whole before proportions of her parts be brought again by this heavenly leech and by medicine of men (as quoted by Tawney 1926: 29).

During the discussion that follows, we emphasize that not only does each member occupy a defined role, members must receive the means suited to their stations in life so that they can carry out their functions. No more than this must be claimed, for, quoting Tawney this time (1926: 27), "if one takes into his hand the living of two, his neighbor will go short." If people run short, are deprived of necessary means, they will not be able to perform their functions.

A passage from John of Salisburg further makes the point:

The health of the whole commonwealth will be assured and vigorous, if the higher members consider the lower and the lower answer in like manner the higher, so that each is in turn a member of every other (John of Salisburg, quoted by Tawney 1926: 29).

Finally, we quote a passage from an unpublished essay of John Locke:

When any man snatches for himself as much as he can, he takes away from another man's heap the amount he adds to his own, and it is impossible for anyone to grow rich except at the expense of someone else (quoted in Spiegel 1971: 165). 
This is generally enough. Now, after brief discussion, we revisit the initial scenario. We ask them how they would now feel, what they might now $d o$, and what they might now reasonably know about the situation if they lived in this other time and conceptualized the world through this other conceptual scheme. This time most indicate they would now feel guilty. Some students insist that they would still feel good about their "steal." We point out that they are thinking with our current conceptual model, not with the organic analogy introduced. Most students eventually see the difference. Admittedly, some never do. What would they now do? Generally they would return to the place of purchase and give the vendor his rightful due. What if it is too far and is not practical to return? With some discussion students usually come up with alternative courses of action: giving the excess to charity; going to church to pray for forgiveness.

To the question about what they might now reasonably know, they explain how, by not having given the vendor his or her "due," the vendor will go short, not be able to perform his or her social duties, and the community, as a whole, will suffer as a consequence. This is because they would be depriving somebody of the necessary means to perform their function in society. When asked to go back and explain why they originally felt good they are still, generally, without a response other than, "Just because it seems like a natural thing to do." But they grasp and understand that something is unconsciously guiding their reactions (how they feel and what they might do) even if they are unable to explain it. And they grasp the importance of understanding what this something is.

\section{Intellectualizing the Experience: the Concept of Culture}

At this point we can intellectualize the experience by introducing the anthropology of Clifford Geertz. Geertz's concept of culture, which he came to by way of the sociology of Talcott Parsons and the philosophies of Susan Langer and Gilbert Ryle, is defined as those "historically transmitted patterns of meanings embodied in symbols, systems of inherited conceptions expressed in symbolic forms," by and through which people "communicate, perpetuate, and develop their knowledge about and attitudes toward life" (1973: 89). It is by and through symbolic models, the imaginative universe within which social action takes place, that humans give form, order, point, and direction to their lives. 
Behind the traditional concept of culture ${ }^{4}$ is an image, referred to by Geertz as the Enlightenment image, of unembellished human beings lying somewhere below, or behind, the trappings of local custom and tradition. This image holds culture to be an addition to an otherwise biologically, neurologically, and anatomically completed animal. Conversely, archaeological evidence strongly suggests that culture, rather than being added on to an otherwise complete animal, was integral to its ultimate formation. Literally, people had a hand (or a mind) in making themselves. Consequently, the mind and the body evolved, at least during the final stages, within the framework of human culture and human symbolization. For this reason, human culture, in the Geertzian sense of systems of symbols and meanings, is not superfluous to human beings: it is defining, it is essential.

The argument can be put in terms of models. The term model has, however, a dual aspect to it: there are models for as well as models of. Models for exist in nature, as in the genetic code, which is a model - a blueprint - for reconstructing another of the same species. But models of are apparently uniquely human. Beavers build their houses, and birds fly south, according to genetic information contained intrinsically; humans build houses, and fly wherever it is they fly - in machines - according to symbolic and extrinsic sources of information, according to models of houses for house building, of aerodynamics for the construction and operation of airplanes.

To fully grasp Geertz's approach, the student must also grasp that human thought is largely a metaphorical process. Human thought consists of the construction and manipulation of symbol systems employed as models of other non-symbolic systems in such a way that the structure of these other systems, and how they may be expected to behave, is "understood."

When we think, conceptualize, formulate, comprehend, understand, or whatever, we match the states and processes of symbolic models against the states and processes of the wider world. "Imaginal thinking is neither more nor less than constructing an image... of the 'relevant features' of the environment and then manipulating it under various hypothetical conditions and constraints" (Galanter and Gerstenhabor 1956, quoted in Geertz 1973: 213).

Conscious perception is, then, a "seeing as" or an "interpreting as" phenomenon. People just don't see something, they are not just conscious of something, they see it and are conscious of it as being something. When they come upon an unfamiliar something they are seldom content to let it remain unfamiliar but immediately ask what 
that certain something is. "What is missing and what is being asked for are an applicable symbolic model under which to subsume the 'unfamiliar something' and so render it familiar" (1973: 215).

Anthropologists make models, too, and Geertz developed a model for the analysis of sacred symbols, a model of religion as a cultural system. It is with and through this model that we feel we can effectively approach the teaching of environmental ethics. We want to stress, again, that our concern is with the precursor to an explicit treatment of environmental ethics, rather than proposing an environmental ethics curriculum.

Sacred symbols function to synthesize a people's worldview and their ethos. Sacred symbols bring a metaphysical acceptance of the way things are, that is, the way they are thought to be (a worldview), together with a moral, aesthetic, or evaluative element (an ethos). The first, the worldview, is a sense of the really real, the concepts of nature, of self, of society, that provide the most comprehensive ideas of the general order of existence within which a people find themselves. The second, the ethos, is an underlying attitude toward life, a comprehensive moral and aesthetic attitude, a recommended style of life. The worldview is an accepted model of reality; the ethos, a model for living in that reality. The juxtaposition of the two gives to the recommended style of life what it needs most if it is to be coercive: the appearance of objectivity, an air of naturalness and simple factuality. Proper conduct is supported "by picturing a world in which such conduct is only common sense" (Geertz 1973: 129). Sacred symbols formulate a basic congruence between a particular style of life and a specific (if, most often, implicit) metaphysic and, in so doing, sustain each with the borrowed authority of the other (Geertz 1973: 90).

All sacred symbol systems assert that it is good for people to live realistically; they differ in the vision of reality that they construct. Those individuals that fail to go along with the moral-aesthetic norms formulated by the symbols, who follow an incongruent style of life (particularly in those societies where such formulations go uncriticized), are regarded not so much evil as stupid, insensitive, unlearned, or mad. For those who are committed to them-and, as anthropologist Edward T. Hall noted, we become very committed to them"men have fought and died in the name of different models of nature" (1977: 14)—sacred symbols mediate genuine knowledge, knowledge of the essential conditions in terms of which life must, of necessity, be lived. 


\section{The Dominant Modern Worldview and the Ethos that it Undergirds}

For many students, understanding that human thought is essentially metaphorical is illuminating; something they have never considered. Geertz's model of sacred symbols, of religion as a cultural system, permits a direct unpacking, a thick-description, of the worldview contained in traditional business courses and a reinterpretation of economic theory as an embodiment of the ethos that the worldview supports. To grasp the idea that there is a worldview lurking behind, or beneath, the ethos, and that this worldview is often implicitly held and unthinkingly accepted, is important in preparing the ground for whatever environmental ethics curriculum is to be taught.

This idea also lies behind our view that whenever we teach anything, we already teach an environmental ethic, a set of beliefs, attitudes, values and standards regarding the environment. It is difficult to recognize this ethic/ethos for what it is because it is unintentionally taught and not formally part of the curriculum (sometimes because instructors are not, themselves, aware of it). Consequently the unconscious teaching of this traditional environmental ethic/ethos is successful and has profound effects. For this reason, students should become consciously aware of their own ethos and of the worldview that underlies it. Geertz's model for the analysis of sacred symbols paves the way.

\section{The Dominant Modern Ethos: the Rules of the Game}

Most MBA students are taught that economics is a science. But economics can be recast as a cultural system and as a symbolic representation of the dominant modern ethos where humans and the rest of nature are seen as distinct, and the earth is seen as a resource and a sink for human wastes (Benton 1982, 1986, 1990).

It is not customary, at least not until recently (see Wight 2002), to ask why a moral philosopher such as Adam Smith was so concerned with increasing "the wealth of nations." After all, he did not place a high value on affluence, and in fact regarded the pursuit of riches as meretricious and its influence corrupting (Rotwein 1973, Wight 1999). So how is it that he was able to concern himself with its annual increase?

In part it was in deference to a matter of distribution: "No society," Smith stated, "can surely be flourishing or happy, of which the 
far greater part of the members are poor and miserable." While Smith is espousing the material well-being of the common people, luxury occupied most of the attention during the seventeenth and eighteenth centuries. Most men of luxury gained their fortunes by trading, transporting, or by lending. In The Quintessence of Capitalism: A Study on the History and Psychology of the Modern Businessman (1915: 34-35), Warner Sombart notes that a fifteenth century architect, musician, and courtier, Battista Alberti, listed wholesale trade, the seeking of treasure trove, the ingratiating oneself with a rich man to become his heir, usury, and the rental of pastures, horses, and the like as the best ways of getting rich. Sombart further cites an unnamed seventeenth century commentator as adding royal service, soldiering, and alchemy to the list.

If the medieval world was, as many have pointed out, a zero-sum game (and as implied in Locke's passage, above), how could Adam Smith advocate increasing the material well-being of the common folk without taking it from the rich? The answer lies in the lists provided by Sombart. Noticeably absent is "manufacturing." What Adam Smith was searching for, and what he bequeathed us, was an institutional order that would eliminate zero-sum games.

Although concentrating human effort on manufacturing, on producing more and more, might be a grand delusion if thought to enhance individual happiness (according to Smith), it would at least contribute to the social welfare. It would do this by contributing to the material well-being of the common people, relieving social tensions (at least those attributed to the inadequate provision for human wants) and contributing to a civil society.

This, of course, is the stance taken by Francis Bacon. The inspiration for true learning was, for Bacon, "not the pleasure of study and the excitement of discovery, but the needs of mankind" (Prior 1964: 47)-although not entirely with the welfare of the common man (Merchant 1983: 177, Mumford 1970).

Bacon's notion of a species ambition urged an enlargement of the power and dominion of the human race over the universe of things. ${ }^{5}$ As a species ambition it was pure because it was not achieved at the expense of other persons or states. (The assumption was, of course, that nature has no interests, an assumption that is, itself, worthy of additional "thick description.") But by what rules, by what institution, should this be made effective? Social living requires some acceptance of and compliance with fixed, if generalized, rules of con- 
duct. And these rules of conduct must be formulated in such a way that everybody understands them, accepts them, and acts accordingly. In order to grasp the real meaning and significance of economic laws, we must think of them as a specific set of rules appropriate for a specific mode of production and distribution found in a particular society.

The Law of Supply and Demand, rather than the symbolic expression of natural laws or natural processes, or even as the representation of statistical regularity, ${ }^{6}$ is our most fundamental expression of a generalized guide for living. The Law of Supply and Demand is a social code. It should be formulated in terms somewhat like the following: "If commercial exchange is to be an effective instrument for want satisfaction, sellers should raise prices when buyers increase their demand," and so on, for its various propositions (Lowe 1942: 439-440). In this way the Law of Supply and Demand provides the beacon from which human action (in a market economy) takes its bearing. Only if people, in fact, act in accordance with the Law of Supply and Demand will the price system function to bring about the social world imagined by economists. The Law of Supply and Demand is a primary "rule of the game," perhaps the rule, of the Dominant Modern Ethos. ${ }^{7}$

\section{Ecology, an Emerging Worldview and Aldo Leopold}

At this point the door has been opened for a discussion of ecology as a science. Since so many environmentalists appeal to ecology, students should be familiar with at least some of the models that have guided ecological research. A brief discussion of ecology, especially the history of ecology, ${ }^{8}$ leads to a direct consideration of Aldo Leopold and his essay, "The Land Ethic." The essay employs many of the concepts discussed in any historical overview of ecology (the community model and the energy flow model, for example); but because Leopold was an ecologist, and appealed to ecology to explain and justify his conclusions, it will have appeal to MBA students who already elevate science and the scientist in the intellectual hierarchy.

As has been pointed out by Callicott (1987), and certainly by others, Leopold's ethics derive from the Scottish Enlightenment that extended from David Hume to and through Charles Darwin. This tradition placed moral sentiments at the center of ethics; and, 
significantly, Adam Smith, author of the Theory of Moral Sentiments, contributed to this tradition. Showing how Adam Smith, the "father" of economics and author of The Wealth of Nations is also the author of the Theory of Moral Sentiments, and in direct line of descent to Aldo Leopold can serve important rhetorical purposes in an environmental ethics class. It may also provide another way to "close the circle" between economics and ecology. ${ }^{9}$

Finally, Leopold's approach to ethics ties in with the general orientation of this paper: that we do not need ethical theories, rules, and principles to decide what is right, but detailed description of the relevant circumstances, including how it is we traditionally view things, in order to act ethically. As Des Jardins points out (2001: 198), "Leopold's ethics is focused less on rules that guide action and more on moral dispositions or virtues."

Any discussion of the science of ecology should make clear that all philosophers do not agree on the lessons to be drawn from ecology. Nor do they agree from which ecological model these lessons should be drawn. However, ecology might suggest new ways for approaching not only the management of environmental issues but the epistemological, metaphysical, and ontological questions that some argue underlie them (Devall and Sessions 1985). That is, we must recognize that many problems are traced to these kinds of deep philosophical questions and ecology may provide different models for thinking about them, models for treating the causes of environmental problems and not just the symptoms (Morowitz 1972, Everndon 1978, Callicott 1986, and Orr 2003).

\section{Conclusion}

To conclude, we offer a personal example that demonstrates a main theme of this paper, while introducing a further thought on the nature of environmental ethics education in general.

One of us regularly teaches an MBA course called Business and the Environment. It is billed as an environmental management class and students consider topics like ISO 14001, the Natural Step, full-cost pricing, and life-cycle analysis. Students always seem to consider the class an ethics class. This past summer, an undergraduate class was taught to a group of American students. All but one was a business 
major. The class, labeled Global Marketing: Environmental Dimensions, was taught in Rome, Italy.

The first week introduced students to environmental issues by reading J. Donald Hughes' Pan's Travail: the Environmental Problems of the Ancient Greeks and Romans (1994). Given the setting, this was chosen because it was an historian's account of the life and times of the ancient Romans - with an environmental focus. The second week they read and discussed an introduction to Karl-Henrik Robèrt's science based systems framework, The Natural Step (Nattrass and Altomare 1999). This is a managerial approach intended to help businesses understand and move toward sustainability.

On the last day of class the students were debriefed. Among the several questions asked of them was the following: "How many of you think this course was an ethics course?" All students in the class raised their hand. A course that has no ethics content in the traditional sense was, nevertheless, perceived by the students taking it to be an ethics class. ${ }^{10}$ What we find particularly interesting here is that the books did not raise ethical issues in anything that would resemble what we believe would be the traditional way of raising them. The students saw the ethical issues on their own. This personal example makes clear that when the environment is considered in a course, it is unmistakable that an unconscious environmental ethic is being challenged - in this case the unconscious environmental ethic that has been part of all the students' other business courses.

This example also illustrates how teaching environmental ethics can be incorporated into almost any course in such a way that it challenges students to temporarily bracket the current modern worldview and ethos. Because the course dealt implicitly with environmental ethics, students were able to see connections and to think critically in ways that may never have been suggested before. This situation, first, allows students to "play" with the material and arrive at conclusions themselves. Second, it opens the door for students to pursue ethical concerns in ways relevant to themselves. These are what we consider to be the goals of education: students are guided and offered the freedom to think as well as inspired to take those thoughts in new directions.

Environmental ethics should be taught consciously because an environmental ethic is already being taught implicitly. But a conscious effort at teaching environmental ethics, if it is to be anything more 
than an exercise in repeating back that which has been learned, must be done in a way that encourages "a self-conscious stepping back" but without providing new rules for analysis and decision making. Students should be given the opportunity to wonder - and wander. The teaching of environmental ethics, therefore, is a prime vehicle of learner-centered teaching and values education.

Corresponding Address: Raymond Benton, Jr. PhD, Loyola University Chicago School of Business Administration, 25 E. Pearson Street, \#1371 Chicago, IL 60611 U.S.A.rbenton@luc.edu; Christine S. Benton, M.A.

\section{Notes}

1. Our dictionary defines ethos as "the disposition, character, or fundamental values peculiar to a specific person, people, culture, or movement."

2. Specifically, we draw on "The Impact of the Concept of Culture on the Concept of Man," "The Growth of Culture and the Evolution of Mind," "Religion As a Cultural System," and on "Ethos, World View, and the Analysis of Sacred Symbols," all in The Interpretation of Cultures (1973). Our general approach to the problem, is, we feel, akin to that of Iris Murdoch (The Sovereignty of Good, 1970), Stanley Hauerwas (Vision and Virtue, 1981) and Peter Levine (Living Without Philosophy, 1998), although none index environment or ecology in their books.

3. We do not know if, in fact, this is the origins of the expression "it was a steal," but when this exercise is complete, students can be asked to reflect on and consider from where this expression might have come.

4. E.B. Tylor first formulated the concept of culture in anthropology. On the first page of his book, Primitive Culture (1871), he defined culture as "that complex whole which includes knowledge, belief, art, law, morals, customs, and any other capabilities and habits acquired by man as a member of society." Culture was everything that man thinks and does that is transmitted extra-genetically.

5. There is an interesting parallel between Bacon's position and that of William James in the latter's essay, "The Moral Equivalent of War" (James 1970, originally 1910).

6. Economist Donald McCloskey has noted that empirical support, even for the most basic and fundamental of economic principles, the Law of Demand, is not too persuasive (1985: 57-62).

7. "We should not be surprised or disappointed," Alasdair MacIntyre wrote, "that the generalizations and maxims of the best social science share certain characteristics of their predecessors - the proverbs of folk societies, the generalizations of jurists, the maxims of Machiavelli (1984: 105)."

8. See, for example, Worster 1985 and Golley 1993.

9. We state at the outset and repeat throughout that we are not concerned with any particular environmental ethics curriculum. We do not hesitate to point out where the approach we adopt leads and how that integrates into what the students already bring (or should bring) with them to class.

10. After asking how many thought it was an ethics class, they were then asked what it was about the class that made it an ethics class. A variety of responses were received. Four student responses follow: 
"I thought the course in Rome could be considered an ethics course because each issue we addressed related to the morality of the situation ... I think your class made us realize that environmental issues are moral issues."

"The course was an ethics course because it made us think twice and gave us a choice. [W] e became aware of issues and choices that we may not have seen in the past, but we should realize because they will affect us in the future."

In the context of a very anthropocentric response, a third student said, and later wrote out for me, this response: "Due to this class, I have come to understand [murder] in a stronger light. Everyday, we as people of this earth, are doing little things that are destroying our home... It was an ethical class because it led us to a crossroads where we have to make a decision to either continue killing or improve this world."

"I thought that our class was an ethics class because it took into consideration the actions of humans on our environment and whether or not those actions were appropriate, morally. We looked at both the "inappropriate" actions as well as what is being done currently to correct our negative impact on our home."

\section{REFERENGES}

Benton, Raymond Jr. 1982. "Economics as a Cultural System", Fournal of Economic Issues 16 (June): 461-469.

- 1986. "Economics and the Loss of Meaning", Review of Social Economy 44 (December): 251-267.

- 1990. "A Hermeneutic Approach to Economics: If Economics Is Not A Science, and If It Is Not Merely Mathematics, then What Is It?" in Warren J. Samuels (ed.) Economics as Discourse. New York: Kluwer Academic Publishing.

Callicott, J. Baird. 1986. "Metaphysical Implications of Ecology", Environmental Ethics 9 (Winter): 300-315.

. 1987. "The Conceptual Foundations of the Land Ethic", in J. Baird Callicott (ed.) Companion to A Sand County Almanac: Interpretive and Critical Essays. Madison, Wisconsin: University of Wisconsin Press.

Des Jardins, Joseph R. 2001. Environmental Ethics: An Introduction to Environmental Philosophy. 3rd edn. Wadsworth.

Devall, Bill and George Sessions. 1985. Deep Ecology. Salt Lake City: Gibbs Smith, Publisher/Peregrine Smith Books.

Everndon, Neil. 1978. "Beyond Ecology", North American Review 263: 16-20.

Galanter E. and M. Gerstenhaber. 1956. "On Thought: the Extrinsic Theory", Psychological Review 63: 218-227.

Geertz, Clifford. 1973. The Interpretation of Culture. New York: Basic Books.

Golley, Frank. 1993. A History of the Ecosystem Concept in Ecology. New Haven, Conn.: Yale University Press.

Hall, Edward T. 1977. Beyond Culture. Garden City, New York: Anchor Press/ Doubleday.

Hargrove, Eugene G. 1980. "Anglo-American Land Use Attitudes," Environmental Ethics (2): 121-148.

Hauerwas, Stanley. 1981. Vision and Virtue: Essays in Christian Ethical Reflection. Notre Dame, Indiana: University of Notre Dame Press.

Hughes, J. Donald. 1994. Pan's Travail: Environmental Problems of the Ancient Greeks and Romans. Baltimore: The Johns Hopkins University Press.

James, William. 1970 [1910]. "The Moral Equivalent of War," in Richard A. Wasserstrom (ed.) War and Morality. Belmont, California: Wadsworth Publishing. 
Leopold, Aldo. 1987 [1949]. "The Land Ethic," in A Sand County Almanac, and sketches here and there. New York: Oxford University Press.

Levine, Peter. 1998. Living Without Philosophy: On Narrative, Rhetoric, and Morality. Albany, NY: State University of New York Press.

Lowe, Adolf. 1942. "A Reconsideration of the Law of Supply and Demand," Social Research 9 (4): 431-457.

MacIntyre, Alasdair. 1984. After Virtue. 2nd edn. Notre Dame, Indiana: University of Notre Dame Press.

Merchant, Carolyn. 1983. The Death of Nature: Women, Ecology and the Scientific Revolution. New York: Harper \& Row.

Morowitz, Harold. 1972. "Biology as a Cosmological Science," Main Currents in Modern Thought 28.

Mumford, Lewis. 1970. The Pentagon of Power: the Myth of the Machine, Volume II. New York: Harcourt Brace Jovanovich.

Murdoch, Iris. 1970. The Sovereignty of Good. London: Routledge \& Kegan Paul.

Nattrass, Brian and Mary Altomare. 1999. The Natural Step for Business: Wealth, Ecology and the Evolutionary Corporation. Gabriola Island, British Columbia, Canada: New Society Publishers.

Orr, Matthew. 2003. "Environmental Decline and the Rise of Religion", Zygon: Fournal of Religion and Science 38: pp. 895-910.

Prior, E. Moody. 1964. "Bacon's Man of Science," in Leonard M. Marsak (ed.) The Rise of Science in Relation to Society. New York: Macmillan.

Rotwein, Eugene. 1973. "The Ideology of Wealth and the Liberal Heritage: A Neglected View", Social Research 40 (Summer): 267-292.

Sombart, Warner. 1967 [1915]. The Quintessence of Capitalism: A Study on the History and Psychology of the Modern Businessman. New York: H. Fertig.

Smith, Adam. 1937 [1776]. An Inquiry into the Nature and Causes of the Wealth of Nations. New York: Modern Library.

Spiegel, Henry William. 1971. The Growth of Economic Thought. Englewood Cliffs, NJ: Prentice-Hall Publishers, Inc.

Tawney, R.H. 1954 [1926]. Religion and the Rise of Capitalism. New York: New American Library/Mentor Books.

Wight, Jonathan B. 1999. "Will the Real Adam Smith Please Stand Up: Teaching Social Economics in the Principles Course", in Edward J. O'Boyle (ed.), Teaching the Social Economics Way of Thinking, Mellen Studies in Economics, Vol. 4, Lewiston, NY: The Edwin Mellen Press: 117-139.

- 2002. "The Rise of Adam Smith: Articles and Citations, 1970-1997", History of Political Economy 34 (1): 55-82.

Worster, Donald. 1985. Nature's Economy. Cambridge, England: Cambridge University Press. 
Copyright of Worldviews: Environment Culture Religion is the property of Brill Academic Publishers and its content may not be copied or emailed to multiple sites or posted to a listserv without the copyright holder's express written permission. However, users may print, download, or email articles for individual use. 